\title{
Sink plot for runoff measurements on semi-flat terrains: preliminary data and their potential hydrological and ecological implications
}

\author{
Giora J. Kidron \\ Institute of Earth Sciences, The Hebrew University of Jerusalem, Givat Ram Campus, Jerusalem 91904, Israel. \\ Tel: +972-54-4967-271. Fax: 972-2-566-2581. E-mail: kidron@mail.huji.ac.il
}

\begin{abstract}
In arid and semiarid regions where water is the main limiting factor, water redistribution is regarded as an important hydrological process of great ecological value. By providing additional water to certain loci, moist pockets of great productivity are formed, characterized by high plant biomass and biological activity. These moist pockets are often a result of runon. Yet, although runoff may take place on semi-flat undulating surfaces, runoff measurements are thus far confined to slopes, where a sufficient gradient facilitates downslope water harvesting. On undulating surfaces of mounds and depressions, such as in interdunes, no quantification of the amount of water reaching depressions is feasible due to the fact that no reliable method for measuring the runoff amounts in semi-flat terrains is available. The current paper describes specific runoff plots, designed to measure runoff in depressions (sinks). These plots, termed sink plots (SPs), were operative in the Hallamish dunefield (Negev Desert, Israel). The paper presents measurements of runoff yield that were carried out between January 2013 and January 2014 on SPs and compared them to runoff obtained from crusted slope plots and fine-grained (playa) surfaces. The potential hydrological and ecological implications of water redistribution within semi-flat terrains for this and other arid ecosystems are discussed.
\end{abstract}

Keywords: Infiltration; Playa surfaces; Sand dunes; Negev Desert.

\section{INTRODUCTION}

In arid and semiarid regions where water is the main limiting factor, water redistribution is regarded as an important hydrological process of great ecological value (Noy-Meir, 1973). One of the main factors that contribute to water redistribution is runoff. Runoff in turn may reach the footslopes either as sheet flow or through gullies.

Indeed, measurements of surface runoff are thus far confined to slopes. With runoff plots being constructed on sloping ground, runoff is harvested downslope. Runoff plots were reported from the Negev Desert (Kidron and Yair, 1997; Kidron et al., 2003; Tadmor and Shanan, 1969; Yair and Lavee, 1985), the southwestern US deserts (Kidron et al., 2012; Schlesinger et al., 2000), the Tabernas Desert (Cantón et al., 2002; RodríguezCaballero et al., 2012), and the northwestern deserts of China (Li, 2003). In all these examples, the amount of water reaching the footslope or the bottom part of the plot was measured. Nevertheless, runoff may also be generated on low-angle surfaces in semi-flat terrains.

Semi flat surfaces characterize many arid and semiarid regions. Typically, they have undulating surfaces, with adjacent mounds and depressions (sinks). In the Jornada Experimental Range (JER), in the northern Chihuahuan Desert (NM, USA) for instance, 1-2 m-diameter and 0.1-0.2 m-deep depressions are characterized by exceptionally high grass cover (Fig. 1a), explained by the addition of runoff from the immediate vicinity (Kidron and Gutschick, 2013). In the Nizzana research site (NRS) within the Hallamish dunefield, western Negev Desert (Israel), similar size depressions are scattered within the interdunes (Fig. 1b), characterized by high-biomass biological soil crusts, BSCs (Fig. 1c). Runoff contribution is thought to account for these high-biomass crusted patches (Kidron and Vonshak, 2012).

Contrary to silty sediments such as in JER which readily generate runoff (Blackburn, 1975), runoff at the sandy dunes of
NRS was generated due to the presence of BSCs. Being composed of cyanobacteria, lichens, mosses, fungi and bacteria (Lange et al., 1992), the biological soil crusts (mostly $\sim 1-3 \mathrm{~mm}$ thick) were found capable of absorbing copious amounts of water, which readily produce runoff under medium and high rain intensities (Kidron, 1999). Alternatively, except for very specific and limited loci, BSCs do not inhabit the playas. Runoff generation at the playa surfaces stems from the non-porous nature of the loessial sediments.

Being a prerequisite for runoff generation on sand (Kidron, 1999), the capability of BSCs to generate runoff was attributed to pore clogging mainly due to exopolysaccharides, EPS (Fischer et al., 2012; Kidron et al., 1999; Mazor et al., 1986), which are principally produced by cyanobacteria (Moore and Tischer, 1964). A positive linear relationship was indeed found between runoff and the total polysaccharides of the cyanobacterial crusts (Kidron et al., 2003). While several consecutive minutes with high intensities of $>20 \mathrm{~mm} \mathrm{~h}^{-1}$ were necessary for runoff production on dry surfaces, intensities as low as $9 \mathrm{~mm} \mathrm{~h}^{-1}$ sufficed to produce runoff on wet surfaces. Lower intensities of 6-7 $\mathrm{mm}$ $\mathrm{h}^{-1}$ sufficed to produce runoff from the fine-grained loessial sediments, attesting to the high responsiveness of the playa surfaces even under relatively low intensities.

All rain segments having consecutive rain intensities capable of runoff generation were short, thus affecting water connectivity. In NRS, only the bottom sections of the plots contributed runoff, with average plot length that contributes runoff being $<5 \mathrm{~m}$ (Kidron, 2011).

Following rain events with medium and high rain intensities, small depressions within the interdunes were occasionally flooded for several hours by a $<10 \mathrm{~cm}$-thick water layer following the cessation of the rain event. Nevertheless, to date, no reliable method is available to measure the runoff amount within semi flat surfaces under natural field conditions, and the contribution of runoff was estimated either through sprinkling experiments (Cerdà, 1997, 1998; Dunkerley, 2012; Li et al., 

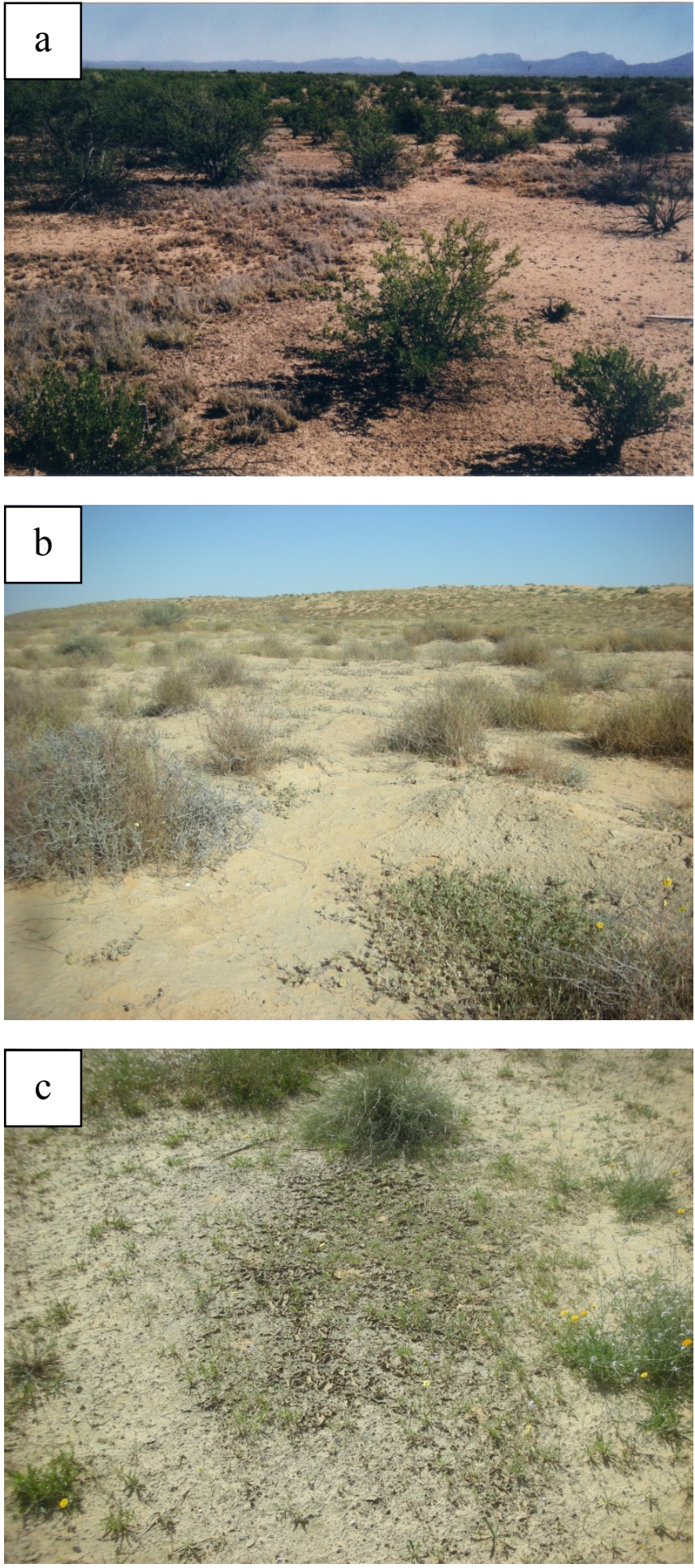

Fig. 1. Small depressions with high cover of perennial grass in the Jornada Experimental Range, JER (a), general view of depressions scattered within the interdunes of the Nizzana research site, NRS (b), and high-biomass biological soil crusts within small depression at NRS (c). Note the dark-colored crusts at the bottom of the depression in NRS.

2008; Malam-Issa et al., 2011; Neave and Abrahams, 2002; Rostagno, 1989) or concluded based either on field observations, or following indirect measurements of the depth of water infiltration (Kidron and Vonshak, 2012). Due to technical constraints, runoff measurements under field conditions were not executed on semi flat surfaces.
Subsequently, no quantification of water reaching these habitats was feasible, nor the study of the relationship between water availability and biological parameters.

The construction of specific runoff plot capable of measuring the runoff amount which reaches concave surfaces such as depression was thus called for. The design of such plots, termed sink plots (SPs), are described herein. Preliminary runoff data following their operation are presented.

\section{MATERIAL AND METHODS}

The research site

The Nizzana research site (NRS) is located in the Hallamish dune field in the western Negev Desert $\left(34^{\circ} 23^{\prime} \mathrm{E}, 30^{\circ} 56^{\prime} \mathrm{N}\right)$. It is comprised of east-west trending longitudinal dunes, up to $20 \mathrm{~m}$ high, separated by 50-200 m interdunes (Breckle et al., 2008). While long-term mean annual precipitation (1950-1980) was 95 $\mathrm{mm}$ (Rosenan and Gilad, 1985), it was only $61 \mathrm{~mm}$ during 1995-2009 (Siegal et al., 2013), falling between November and April. Mean daily annual temperature is $20^{\circ} \mathrm{C}$; it is $26.5^{\circ} \mathrm{C}$ during the hottest month of July and $11.8^{\circ} \mathrm{C}$ during the coldest month of January. Annual potential evaporation is $\sim 2600 \mathrm{~mm}$ (Evenari, 1981).

Most of the sandy dunes are covered by BSCs. BSCs cover all sandy interdunes and the middle and bottom parts of the dunes. They do not cover the dune crests, where wind velocity is too high to facilitate their establishment, and patches of finegrained flat sediments, termed playas, which were deposited during severe floods by the adjacent Nahal Nizzana.

Five types of crusts were defined in NRS, four cyanobacterial crusts (crusts A-D) and one moss-dominated crust (crust E). Whereas crust A, the most xeric crust, inhabit the interdunes and the south-facing slopes, all other crusts inhabit the north-facing slopes, with crusts B-D extending over most of the slope, while crust $\mathrm{E}$ occupies the interface between the north-facing footslope and the interdune (Kidron et al., 2010). While Microcoleus vaginatus predominates in crust A and B, it is accompanied by Nostoc sp., Scytonema sp. and Calothrix cf. parietina in crusts $\mathrm{C}$ and D. Two moss species Bryum dunense and Tortula brevissima predominate at crust $\mathrm{E}$.

\section{Design of sink plots (SPs)}

During preliminary experiments, the feasibility of measuring runoff within the depressions was explored by inserting 21 bottles at different locations within the interdune of NRS. In order to guarantee a minimal disturbance to the surface, the BSCs were wetted and then carefully removed prior to the insertion of the bottle, and re-placed thereafter. Following preliminary measurements during 2009/10, the amount of water harvested by bottles inserted at the top of the mounds or at their slopes was similar to the hydrological rain (as measured by small-orifice rain gauges installed adjacent to the bottles). This was however not the case with the bottles at the bottom of the depressions which were entirely filled with water (Fig. 2a), implying, that the amount of water reaching the bottom part of the depression stems from runoff. Additionally, as can be seen in Figure 2a, crust transplant was successful. No traces of the transplantation process were visible following 15-20 $\mathrm{mm}$ of precipitation, whether falling during one high-depth rain event or during a few successive low-depth rain events. No erosion of the transplanted crust was noted and thus, one can assume that the hydrological properties of the natural surface were thereafter only negligibly affected. 

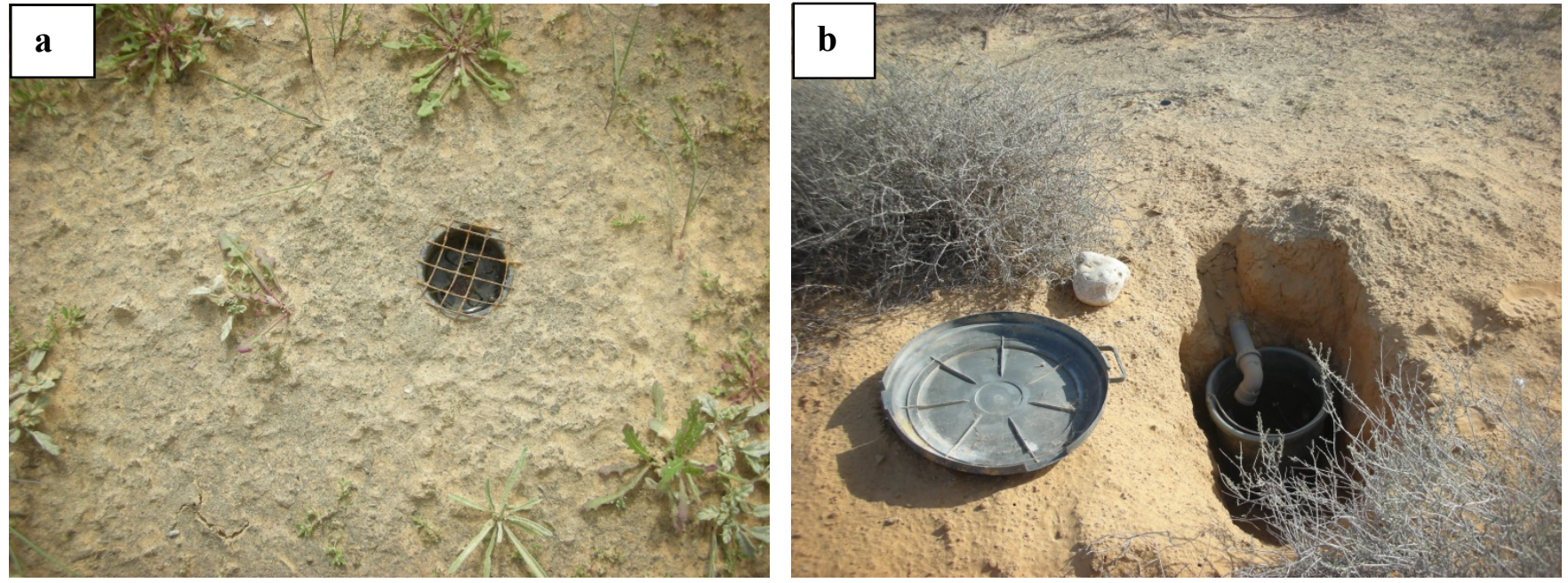

Fig. 2. A 21 bottle totally filled with runoff water (as indicated by water reflectance) at the bottom of a depression at the interdune of NRS (a) and a sink plot in the field (b).

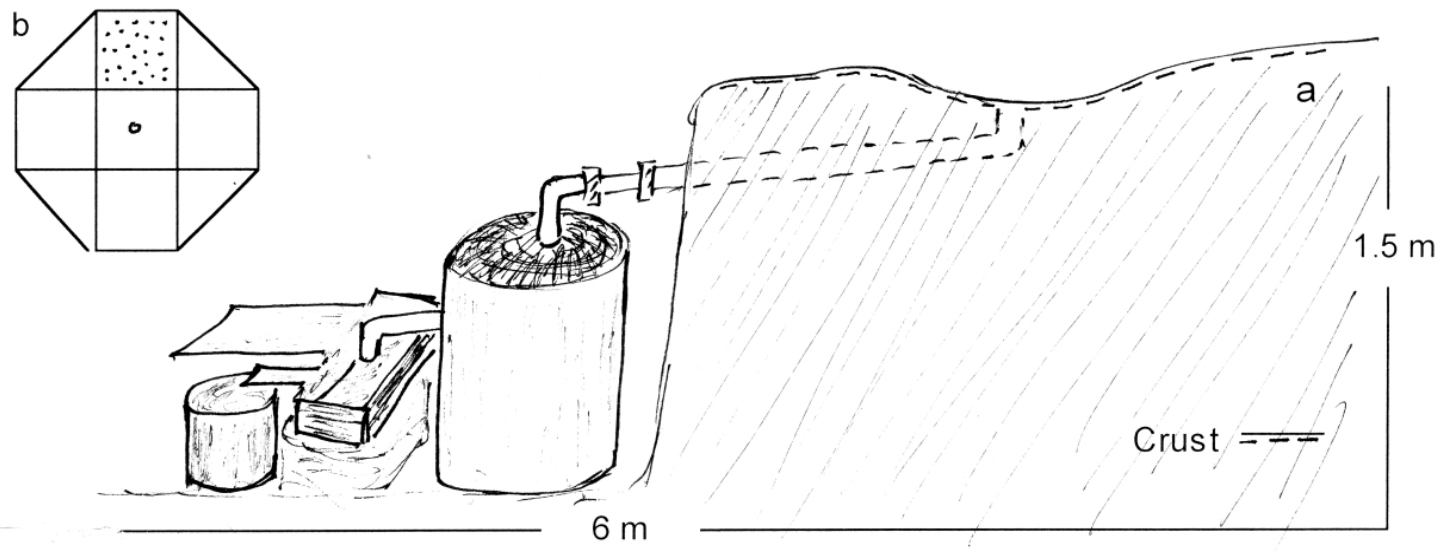

Fig. 3. Schematic drawing of the sink plot, SP (a) and a schematic octagon-shaped planar layout (b). The surface of a typical slope plot (dotted) is approximately $1 / 7$ of the surface area that contributes runoff to the collecting bucket of SP.

Following these preliminary measurements, a sink plot (SP) was constructed (Fig. 2b). A schematic drawing of the SP (along with its planar extension, relative to a slope plot) is shown in Figure 3. It is composed of an opening at the center of the depression, which is connected to a $5 \mathrm{~cm}$-diameter pipe. The pipe, inserted $\sim 10 \mathrm{~cm}$ under the depressions and the adjacent mounds, leads to a 601 container (bucket 1), which is placed in a deep hole, beyond the limits of the monitored depression. In this way, water flow by gravity is facilitated. In addition, in order to allow for measurements of large water quantities (>60 1), extra water was channeled from bucket 1 to a 121 -size splitting device which channeled $10 \%$ of the excess water to a small 101 bucket (bucket 2), while allowing the remaining $(90 \%)$ water to flow out. By multiplying the water caught in bucket 2 by ten and adding the amount within bucket 1 and the splitting device, the total amount of runoff was obtained.

For the evaluation of the potential area which serves as a source area for the sink, the local water divide bordering each sink was demarcated using a rope. The surface area enclosed within the rope was calculated.

\section{Runoff measurements}

Three pairs of plots were demarcated during 2013 at NRS $\left(34^{\circ} 23^{\prime} \mathrm{E}, 30^{\circ} 58^{\prime} \mathrm{N}\right)$; two sink plots (SP) at the depressions within the interdune; two plots on the cyanobacterial crust $\mathrm{C}$ on the north-facing slope, i.e., crusted plots (CP), and two at the semiflat fine-grained sediments, i.e., playa plots (PP). Whereas the SPs were established on crust A (having an average chlorophyll $a$ content of $17 \mathrm{mg} \mathrm{m}^{-2}$ ), the plots at the north-facing slopes were constructed on crust $\mathrm{C}$ (with an average chlorophyll $a$ content of $29 \mathrm{mg} \mathrm{m}^{-2}$ ). Plot properties are shown in Table 1. All plots were equipped with 601 buckets and splitting devices to allow for runoff collection. Runoff was measured following each rain event. Rain and runoff were measured between January 2013 and January 2014. 
Table 1. Properties of runoff plots. $\mathrm{M}=$ mean; $\mathrm{S}=$ standard deviation. $\mathrm{BDL}=$ below detection limits. For species composition: $\mathrm{MIC}=$ Microcoleus vaginatus, $\mathrm{PHO}=$ Phormidium $\mathrm{sp} ., \mathrm{NOS}=$ Nostoc $\mathrm{sp} ., \mathrm{SCY}=$ Scytonema $\mathrm{sp} . \mathrm{CAL}=$ Calothrix cf. parietina .

\begin{tabular}{|c|c|c|c|c|c|c|}
\hline Type of plot & $\begin{array}{c}\text { Surface area } \\
\left(\mathrm{m}^{2}\right)\end{array}$ & & & $\begin{array}{l}\text { Crust thickness } \\
\text { (mm) }\end{array}$ & $\begin{array}{c}\text { Chlorophyll } a \\
\quad\left(\mathrm{mg} \mathrm{m}^{-2}\right)\end{array}$ & Species composition \\
\hline Sink Plot & $11-22$ & Center & $\mathrm{M}$ & 2.6 & 59.8 & MIC \\
\hline \multirow[t]{3}{*}{ (SP) } & & & $\mathrm{S}$ & 0.4 & 20.0 & \\
\hline & & Margins & $\mathrm{M}$ & 1.5 & 16.7 & MIC, $\mathrm{PHO}$ \\
\hline & & & $\mathrm{S}$ & 0.2 & 9.8 & \\
\hline Playa Plot & $1.5-1.9$ & & $\mathrm{M}$ & 2.5 & BDL & \\
\hline (PP) & & & $\mathrm{S}$ & 0.5 & & \\
\hline Crusted Plot & $2.3-4.7$ & & $\mathrm{M}$ & 2.0 & 28.5 & MIC; NOS; SCY \\
\hline (CP) & & & $\mathrm{S}$ & 0.4 & 16.7 & CAL \\
\hline
\end{tabular}

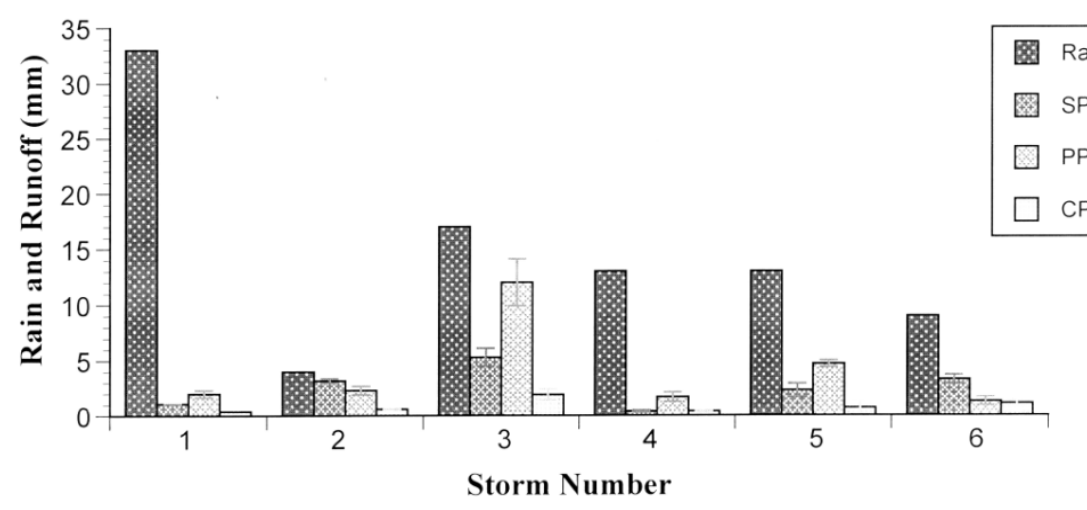

Fig. 4. Rain and runoff yield of the sink plots (SPs), playa plots (PPs), and crusted plots (CPs) during 6 events (Jan 2012 to Jan 2013 ) at the research site. Bars represent one SE.

\section{RESULTS AND DISCUSSION}

Rain precipitation during the study period is shown in Table 2. Runoff was produced during 6 rain events. Figure 4 shows the amounts of rain and runoff during the six runoff events.

For the most parts runoff yield followed the pattern $\mathrm{PP}>\mathrm{SP}>\mathrm{CP}$. The playa plots yielded the highest amounts of runoff (although not significantly different from SP) despite the absence of BSCs there (Fig. 5). This is expected given the high responsiveness of loessial sediments to rain and the relatively low intensities of $5-8 \mathrm{~mm} \mathrm{~h}^{-1}$ necessary for runoff generation on loess (Bertoni et al., 1958; Blackburn, 1975; Tadmor and Shanan, 1969; Valentin and Bresson, 1992).

Table 2. Runoff-induced rainstorms during January 2013 and January 2014.

\begin{tabular}{ccc}
\hline $\begin{array}{c}\text { Storm } \\
\text { number }\end{array}$ & $\begin{array}{c}\text { Date of } \\
\text { rainstorm }\end{array}$ & $\begin{array}{c}\text { Rain } \\
\text { amount }(\mathrm{mm})^{1}\end{array}$ \\
\hline 1 & $8-10.1 .13$ & 33 \\
\hline 2 & 27.1 .13 & 5.5 \\
\hline 3 & 18.11 .13 & 17 \\
\hline 4 & $11-12.12 .13$ & 13 \\
\hline 5 & 30.12 .13 & 13 \\
\hline 6 & $9-10.1 .14$ & 9 \\
\hline
\end{tabular}

\footnotetext{
${ }^{1}$ As measured in the field.
}

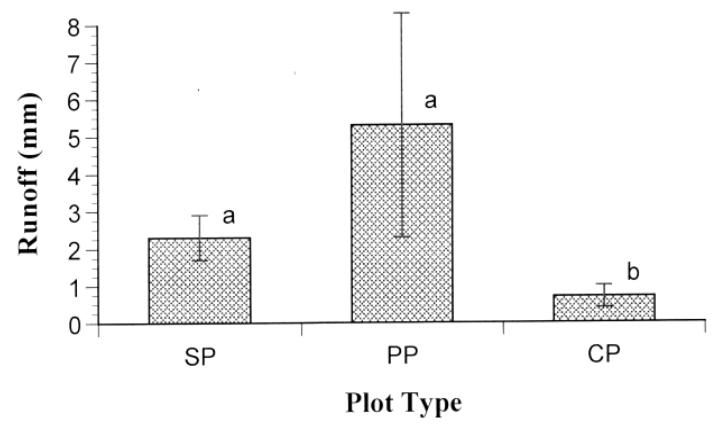

Fig. 5. Average amount of runoff as obtained at the sink plots (SPs), playa plots (PPs), and crusted plots (CPs) during 6 runoff events. Different letters indicate significant differences $(P<0.05)$. Bars represent one SE.

SPs yielded relatively high amounts of runoff. This was evidenced by the occasional flooding that took place at the depressions, and subsequently, by the high-biomass crusts that developed at the bottom of these depressions. These loci have substantially higher chlorophyll and EPS contents in comparison to the crusted sloping surfaces (termed herein margins) of the depressions (Kidron and Vonshak, 2012), characterized by crust A. Nevertheless, it is argued herein that while some of these high-biomass crusts at the bottom of the depression may contribute runoff, its relatively low surface area and its low angle surfaces may make for only a small contribution to the overall runoff yield of the depression. 
Unlike regular runoff plots that are constructed along the slope (with the plot opening at the plot's downslope, see Fig. 3b), simultaneous water flow to the center of the depression (where water entry occurs into the pipe that leads to the buckets) takes place from all directions. Since flow connectivity depends on consecutive rain segments having medium and high intensities to facilitate flow, and following the short duration of consecutive medium and high intensities in NRS (Kidron, 2011), the shorter the traveling distance, the lower the likelihood of runoff loss during travel, and the higher the runoff yield recorded. This is in agreement with previous results that showed a clear scale effect during which small runoff plots yielded the highest runoff coefficients and the highest amounts of runoff per unit area (Kidron, 2011). Furthermore, although an increase in runoff coefficients with crust biomass was observed at the cyanobacterial crusts (Kidron et al., 2003), small-size lowbiomass plots were found to yield higher runoff coefficients than large-size high-biomass plots, highlighting the importance of traveling time for runoff harvest (e.g. Figs 6, 7 in Kidron, 2011).

The current findings have important potential hydrological and ecological implications. The high responsiveness of the sink plots which results in the relatively high runoff yield of these plots, highlight the importance of small depressions within the interdunes. Contrary to the widely accepted perception that regard slopes and especially footslopes as habitats which are mostly benefited from runoff, the current data highlight the role played by small size depressions at semi-flat terrain as a potent important sink for runon. Furthermore, contrary to conventional runoff plots which are confined to sloping grounds and are mainly used to assess runoff yield at a meso (slope) scale, the current SPs facilitate measurements at a micro scale even at semi-flat terrains. This may facilitate in turn precise calculations regarding the interrelations between water and plant (and BSC) biomass, and may explain apparently contradicting recorded data regarding the relationships between rain amounts and productivity on a meso scale (Veste et al., 2011).

With wetness duration being the primary factor explaining BSC biomass and type (Kidron et al., 2010), and exhibiting a close link with subsurface water content (Kidron and Benenson, 2014), water concentration at the depression is reflected not only by the high-biomass crusts at the center of the depression but also in substantially deeper water infiltration (Kidron and Vonshak, 2012). A similar phenomenon was also reported from the loessial terrains of JER where runoff were observed to concentrate in small, 1-2 m-diameter depressions and which, as a result, were characterized by higher water content and highbiomass perennial grasses (Kidron and Gutschick, 2013).

Given the importance of water redistribution in the productivity of arid and semiarid regions, knowledge regarding the spatial distribution of water, including its contribution to small depressions (sinks) at semi-flat basins is of great importance. By facilitating the quantitative assessment of the amounts of water reaching the depressions, the use of SPs will enable a better understanding of the interrelations between physiological properties of plants, water availability, and the plant's distributional patterns (Pockman and Sperry, 2000). This will facilitate a better link between water, productivity and fecundity (Brooks, 2003; Eckstein, 2005), and may also serve as a potent tool for the assessment of microbial (Yu et al., 2012) as well as for soil forming (McFadden et al., 1998) processes.

Acknowledgments. I would like to thank Shimon Y. Tal for the drawing of figure 3, Joel Roskin for his valuable suggestions, and Carol A. Kidron for the editing. The comments of two anonymous reviewers are appreciated.

\section{REFERENCES}

Bertoni, J., Larson, W.E., Shrader, W.D., 1958. Determination of infiltration rates on Marshall silt loam from runoff and rainfall records. Soil Sci. Soc. Am. Proc., 22, 571-575.

Blackburn, W.H., 1975. Factors influencing infiltration and sediment production of semiarid range lands in Nevada. Water Resour. Res., 11, 929-937.

Breckle, S.-W., Yair, A., Veste, M. (Eds.), 2008. Arid Dune Ecosystems-The Nizzana Sands in the Negev Desert. Ecological Studies 200, Springer, Berlin, Heidelberg, New York.

Brooks, M.L., 2003. Effects of increased soil nitrogen on dominance of alien annual plants in the Mojave Desert. J. Appl. Ecol., 40, 344-353.

Cantón, Y., Domingo, F., Sole-Benet, A., Puigdefábregas, J., 2002. Influence of soil-surface types on the overall runoff of the Tabernas badlands (south-east Spain): field data and model approaches. Hydrol. Process., 16, 2621-2643.

Cerdà, A., 1997. The effect of patchy distribution of Stipa tenacissima L. on runoff and erosion. J. Arid Environ., 36, 37-51.

Cerdà, A., 1998. The influence of aspect and vegetation on seasonal changes in erosion under rainfall simulation on a clay soil in Spain. Can. J. Soil Sci., 78, 321-330.

Dunkerley, D., 2012. Effects of rainfall intensity fluctuations on infiltration and runoff: rainfall simulation on dryland soils, Fowlers Gap, Australia. Hydrol. Process., 26, 2211-2224.

Eckstein, R.L., 2005. Differential effects of interspecific interactions and water availability on survival, growth and fecundity of three congeneric grassland herbs. New Phytol., $166,525-536$.

Evenari, M., 1981. Ecology of the Negev Desert, a critical review of our knowledge. In: Shuval, H. (Ed.): Developments in Arid Zone Ecology and Environmental Quality. Balaban ISS, Philadelphia, pp. 1-33.

Fischer, T., Yair, A., Veste, M., 2012. Microstructure and hydraulic properties of biological soil crusts on sand dunes: a comparison between arid and temperate climate. Biogeosciences Discussions, 9, 12711-12734.

Kidron, G.J., 1999. Differential water distribution over dune slopes as affected by slope position and microbiotic crust, Negev Desert, Israel. Hydrol. Process., 13, 1665-1682.

Kidron, G.J., 2011. Runoff generation and sediment yield on homogeneous dune slopes: scale effect and implications for analysis. Earth Surf. Process. Landf., 36, 1809-1824.

Kidron, G.J., Benenson, I., 2014. Biocrusts serve as biomarkers for the upper $30 \mathrm{~cm}$ soil water content. Journal of Hydrology, 509, 398-405.

Kidron, G.J., Gutschick, V., 2013. Soil moisture correlates with shrub-grass association in the Chihuahuan Desert. Catena, $107,71-79$.

Kidron, G.J., Vonshak, A., 2012. The use of microbiotic crusts as biomarkers for ponding, subsurface flow and soil moisture content and duration. Geoderma, 181-182, 56-64.

Kidron, G.J., Yair, A., 1997. Rainfall-runoff relationships over encrusted dune surfaces, Nizzana, western Negev, Israel, Earth Surf. Process. Landf., 22, 1169-1184.

Kidron, G.J., Yaalon, D.H., Vonshak, A., 1999. Two causes for runoff initiation on microbiotic crusts: hydrophobicity and pore clogging. Soil Sci., 164, 18-27. 
Kidron, G.J., Yair, A., Vonshak, A., Abeliovich, A., 2003. Microbiotic crust control of runoff generation on sand dunes in the Negev Desert. Water Resour. Res., 39, 1108.

Kidron, G.J., Vonshak, A., Dor, I., Barinova, S., Abeliovich, A., 2010. Properties and spatial distribution of microbiotic crusts in the Negev Desert. Catena, 82, 92-101.

Kidron, G.J., Monger, H.C., Vonshak, A., Conrod, W., 2012. Contrasting effects of microbiotic crusts on runoff in desert surfaces. Geomorphology, 139-140, 484-494.

Lange, O.L., Kidron, G.J., Büdel, B., Meyer, A., Killian, E., Abeliovich, A., 1992. Taxonomic composition and photosynthetic characteristics of the "biological soil crusts" covering sand dunes in the Western Negev Desert. Functional Ecology, 6, 519-527.

Li, X.J., Li, X.R., Song, W.M., Gao, Y.P., Zheng, J.G., Jia, R.L., 2008. Effects of crust and shrub patches on runoff, sedimentation, and related nutrient $(\mathrm{C}, \mathrm{N})$ redistribution in the desertified steppe zone of the Tengger Desert, Norhern China. Geomorphology, 96, 221-223.

Li, X.Y., 2003. Gravel-sand mulch for soil and water conservation in the semiarid loess region of northwest China. Catena, 52, 105-127.

Malam Issa, O., Valentin, C., Rajot, J.L., Cerdan, O., Desprats, J.-F., Bouchet, T., 2011. Runoff generation fostered by physical and biological crusts in semi-arid sandy soils. Geoderma, 167-168, 22-29.

Mazor, G., Kidron, G.J., Vonshak, A., Abeliovich, A., 1996. The role of cyanobacterial exopolysaccharides in structuring desert microbial crusts. FEMS Microbiol. Ecol., 21, 121130.

McFadden, L.D., McDonald, E.V., Wells, S.G., Anderson, K., Quade, J., Forman, S.L., 1998. The vesicular layer and carbonate collars of desert soils and pavements: formation, age and relation to climate change. Geomorphology, 24, 101-145.

Moore, B.G., Tischer, R.G., 1964. Extracellular polysaccharides of alga: effects on life-support systems. Science, 145, 586.

Neave, M., Abrahams, A.D., 2002. Vegetation influences on water yields from grasslands and shrubland ecosystems in the Chihuahuan Desert. Earth Surf. Process. Landf., 27, 1011-1020.
Noy-Meir, I., 1973. Desert ecosystems: environment and producers. Annu. Rev. Ecol. System., 5, 25-51.

Pockman, W.T., Sperry, J.S., 2000. Vulnerability to xylem cavitation and the distribution of Sonoran Desert vegetation. Am. J. Bot., 87, 1287-1299.

Rodriguez-Caballero, E., Cantón, Y., Chamizo, S., Afana, A., Solé-Benet, A., 2012. Effects of biological soil crusts on surface roughness and implications for runoff and erosion. Geomorphology, 145-146, 81-89.

Rosenan, N., Gilad, M., 1985. Atlas of Israel. Meteorological data, sheet IV/2. Jerusalem (Israel), Carta.

Rostagno, C.M., 1989. Infiltration and sediment production as affected by soil surface conditions in a shrubland of Patagonia, Argentina. J. Range Manag., 42, 382-385.

Schlesinger, W., Ward, T.J., Anderson, J., 2000. Nutrient losses in runoff from grassland and shrubland habitats in southern New Mexico: II. Field plots. Biogeochemistry, 49, 69-86.

Siegal, Z., Tsoar, H., Karnieli, A., 2013. Effects of prolonged drought on the vegetation cover of sand dunes in the NW Negev Desert: Field survey, remote sensing and conceptual modeling. Aeolian Res., 9, 161-173.

Tadmor, N.H., Shanan, L., 1969. Runoff Inducement in an arid region by removed vegetation. Soil Sci. Soc. Am. J., 33, 790-794.

Valentin, C., Bresson, L.-M., 1992. Morphology, genesis and classification of surface crusts in loamy and sandy soils. Geoderma, 55, 225-245.

Veste, M., Breckle, S.-W., Eggert, K., Littmann, T., 2011. Vegetation pattern in arid sand dunes controlled by biological soil crusts along a climatic gradient in the northern Negev Desert. Basic Appl. Dryland Res., 5, 1-16.

Yair, A., Lavee, H., 1985. Runoff generation in arid and semiarid zones. In: Anderson, M.G., Burt, T.P. (Eds.): Hydrological Forecasting. John Wiley \& Sons. Chichester. pp. 183-220.

Yu, J., Kidron, G.J., Pen-Mouratov, S., Wasserstrom, H., Barnes, G., Steinberger, Y., 2012. Do development stages of biological soil crusts determine activity and functional diversity in a sand-dune ecosystem? Soil Biol. Biochem., 51, $66-72$.

Received 5 June 2014 Accepted 17 July 2014

Note: Colour version of Figures can be found in the web version of this article. 